\title{
Determination of Sex From Sternal Dimensions in Upper Egypt Population By Using Multislice Computed Axial Tomography
}

\author{
Khaled M. Abdel Aal ${ }^{1}$ and Hazem A. Yossef ${ }^{2}$ \\ ${ }^{1}$ Departments of Forensic Medicine and Clinical Toxicology \\ ${ }^{2}$ Department of Radiodiagnosis
}

Faculty of Medicine, University of Assiut, Assiut, Egypt

\begin{abstract}
Sex determination is an important step in personal identification which can be done from bones examination either from their metric measurements or radiograph images especially in difficult identification as dismemberments, mutilations and explosions. The present study was designed to assess the possibility of sex determination from sternal measurements by multislice computed axial tomography (MSCT) and generate statistical equations that can be used to determine sex from sternum in Upper Egypt persons. This study was performed on one hundred and sixty healthy living Upper Egypt persons (80 males and 80 females) of age 18-80 years old during MSCT investigation of the chest region, in department of radiodiagnosis in Assiut University hospital after informed consent. Fourteen sternal measurements were taken including manubrium length, sternal body length, combined length of the manubrium and sternal body, sternal index, manubrium width at tip, width and base, sternal body width at articulation with $2^{\text {nd }}, 3^{\text {rd }}, 4^{\text {th }}, 5^{\text {th }}$ and $6^{\text {th }}$ ribs and two virtual angles of sternum. First angle lies between two intersected virtual lines made along the lateral aspect of the upper part of the sternal body and the lateral aspect of the manubrium. Second angle lies between two virtual lines drawn along the lateral margins of the lower part of sternal body and xiphoid process. The data were analyzed statistically. Results of this study demonstrated that the male measurements showed higher statistical significant values than females measurements except sternal index. Use of the multiple and simple regression equations of relation between sternal measurements and sex demonstrated that the total body length was the most significant parameter for sex prediction. The discriminant function analysis revealed correct sex prediction in known Upper Egyptians by 93\%. The multivariant logistic regression can give correct sex prediction in unknown Upper Egyptians by 85.4\%. This study concluded that sex determination can be done through sternal measurements including the virtual sternal angles, the MSCT is a trustful method for bone measurement during forensic investigation and sex prediction from measurements of all sternal parts is higher than those from single part.
\end{abstract}

Keywords Sex, Sternum, Computed axial tomography, Upper Egypt.

\section{Introduction}

$\mathrm{S}$ ex determination is an important step in personal identification during medicolegal investigations (Changani et al., 2014). Identification may be difficult in cases where the integrity of the body has been compromised such as animal scavenging, burning, dismemberment, criminal mutilations and mass disasters. In such cases the forensic examiner can depend on bone measurements (Sen et al., 2011 and Zheng et al., 2012).
The osseous skeleton which resists putrefaction for a long time is useful for sexing the individual (Hunnargi et al., 2008). The pelvis is considered the most reliable element to be used for sex determination but it is fragile and susceptible to damage (Walker, 2005). The skull has been established to be less accurate than post cranial elements by meteric measurements (Spradley and Jantz, 2003). 
The human sternum is a flat bone that forms the middle of the anterior part of the thoracic cage. The manubrium is attached to the upper part body of the sternum at its lower border by the symphysis type of joint, while its upper margin, known as jugular notch. On the sides, manubrium contains facets for the articulation of first and half of the second rib. The body of sternum is attached to the xiphoid process at the lower margin. On the lateral margins it contains facets for the articulation of second to sixth ribs (Standring, 2008).

The sternum is one of such bones which is being extensively used for sex identification either by direct measurement of dried sternums from cadavers or indirect measurement of images obtained from chest radiographs (Torwalt and Hoppa, 2005).

Many studies analyze the applicability of Hyrtl's law for sex determination from sternum. This law states that the mesosternum is greater than twice the length of the manubrium in males and in females the length of the manubrium is greater than half the length of the mesosternum (Bongiovanni and Spradley, 2012).

The modern cross-sectional imaging techniques have revolutionized forensic medicine. Virtual anthropology obtained by the threedimensional (3D) imaging techniques such as computer tomography (CT) allow us to visualize almost every anatomical and pathological structure with a high resolution and quality (Benazzi et al., 2010).

The multi-slice computed tomography (MSCT) is becoming more and more widely used for post-mortem examinations (Dirnhofer et al., 2006). In certain cultural circles where conventional autopsy is stigmatized or even forbidden, virtual autopsy would allow sound medicolegal practice without violating religious prohibitions or personal reservations (Weber, 2001).

Computed tomography (CT), provides the opportunity for 3D imaging of the skeleton from scans during clinical examination of known individuals in situ (Decker et al., 2011). In addition CT allows investigation of anatomic regions that are not easily available by autopsy and allows fractures and inner organs to be seen "in situ. Also CT provides documentation in digital form (easily stored) which permits review by others and provides pictures that may be more suitable for presentation in court than autopsy photos (Leth, 2009).

Computed axial tomography is used for sex determination from different bones in different countries as first lumber vertebra (Zheng et al., 2012), the medial clavicular epiphysis (Kellinghaus et al., 2010), pubic bones (López- Alcaraz et al., 2013).

Computed axial tomography was used for sex determination from bones in Egyptian studies from different bones as mandible (Kharoshah et al.,
2010), hand bones length (Eshak et al., 2011), metacarpal bones (Zaher et al., 2011), proximal end of femur (Mostafa et al., 2012), maxillary sinus (Amin and Hassan, 2012), pars petrosa of ossis temporalis of skull (Abd-elhakim et al., 2012).

Computed tomography was used for determination of sex from discrete traits of the sternum and ribs in different population such as in Bosnian (Kimmerle et al., 2008), in French (Verna et al. 2013) in Indian and (Changani et al., 2014).

Although there were a lot of articles about determination of sex from sternal measurements have been published abroad, the validity of these sternal measurements for sex determination of Upper Egyptians using computed axial tomography has not been investigated or published.

\section{Aim of the Work}

First, to investigate the possibility of sex determination from different sternal measurements of Upper Egypt population by MSCT. Second, to evaluate the significance of every part of sternal measurements and virtual sternal angles in sexual dimorphism. Third to formulate a model equation that can be used for sex determination from certain sternal measurements in unknown Upper Egypt individuals.

\section{Subjects and Methods \\ Subjects}

One hundred and sixty apparently healthy Upper Egypt individuals ( 80 were males and 80 were females) were included in this study in Assiut University Hospital after giving an informed consent. The individuals included in this prospective study were randomly selected from patients presenting at the radiodiagosis department for thorax CT investigation with various complaints between Jul. to Dec. 2013. Patients aged 18-80 years. Exclusion criteria include persons suffered from congenital or acquired sternal deformities, traumatic chest injuries and pathological diseases as emphysema, tumors, and cysts.

\section{Methods}

All MSCT examinations were obtained on a 16MDCT (multidetector computed tomography) scanner (Bright Speed, General Electric Medical Systems, Milwaukee USA). A standard protocol was implemented for all MSCT examinations. Patients were scanned cranio-caudally from the thoracic inlet through the lung bases within a single breath-hold. The scans were obtained with $16 \times 1 \mathrm{~mm}$ collimation and a table feed of $6 \mathrm{~mm}$ per $0.8 \mathrm{sec}$ scanner rotation, which resulted in a beam pitch coefficient of 1.5.

Scanning was performed at $120 \mathrm{kV}$ and 200 $\mathrm{mAs} / \mathrm{slice}$. The volumetric MDCT data were reconstructed into axial and MPR $0.625 \mathrm{~mm}$-thick sections. Then, volume rendered shaded-surface 
display (SSD) images were generated and used for the presentation of the sternum and other osseous elements of the chest. Measurement of the distances and angles were done from the axial images as well as from the volume rendered SSD images using electronic cursors.

\section{Morpho-Metric Image Analysis}

Fourteen morpho-metric sternal measurements were used including the manubrium length, sternal body length, combined length of the manubrium and sternal body, sternal index, width of manubrium (base, waist and tip) and body width at levels of articulation with $2^{\text {nd }}, 3^{\text {rd }}, 4^{\text {th }}, 5^{\text {th }}$ and $6^{\text {th }}$ ribs (Iscan, 1985, Torwalt et al. 2005 and Ramadan et al., 2010). The first (upper) and second (lower) sternal angles (Saldin, 2010). All sternal measurements were demonstrated in figure (1:a-b-c) which represents schematic diagrams of sternal dimensions.

1. Length of the manubrium (M): The longest distance from the midpoint of the manubrium and manubriosternal junction.

2. Length of the sternal body (B): The longest distance between manubriosternal junction and mesoxiphoid junction.

3. Combined length of the manubrium and body (CL): Sum of $M$ and $B(M+B)$.

4. Sternal index (SI): It is the division of $\mathrm{M}$ by $\mathrm{B}$, then multiplied by 100 [(M/B) x 100].

5. Width of the manubrium waist, The manubrium width at the level of the line passing on the upper part of incisura costalis (notches or facets on the lateral edge of the sternum at point of articulation with the first costal cartilage).

6. Width of the manubrium base: The manubrium width at the level of the line passing on the lower part of right and left incisura costalis (notches or facets on the lateral edge of the sternum at point of articulation with the first costal cartilage.

7. Width of manubrium tip. Transverse distance of lower part of manubrium.

8. Width of sternal body at the level of midpoint of articulation with $2^{\text {nd }}$ rib.

9. Width of the sternal body at the level of midpoint of articulation with $3^{\text {rd }}$ rib.

10. Width of the sternal body at the level of midpoint of articulation with $4^{\text {th }}$ rib.

11. Width of the sternal body at the level of midpoint of articulation with $5^{\text {th }}$ rib.

12. Width of the sternal body at the level of midpoint of articulation with $6^{\text {th }}$ rib.

13. First (upper) sternal angle was measured between two intersected virtual lines made along the lateral aspect of the upper part of the body of sternum and another line along the lateral aspect of the manubrium sterni.

14. Second (lower) sternal angle was measured between two virtual lines drawn along the lateral margins of the lower part of the body of the sternum and xiphisternum.

\section{Ethical Consideration}

This work was done after approval from the ethical committee of Faculty of Medicine, Assiut University. Informed consent was taken from all individuals participated in this study. Confidentiality of information obtained from all persons included in the study or excluded during CT examination as they required medical interference. Confidentiality was maintained by keeping the medical reports anonymous.

\section{Statistical Analysis}

The data collected were organized, tabulated, entered into a computer database program using SPSS (Statistical Package for the Social Sciences) software version 20. Results are expressed as minimum, maximum, mean \pm standard deviation (SD). The student's t-test was used for independent samples to compare values between males and females. When $\mathrm{p}$. value $\leq=0.01$ is highly significant, $\leq=0.05$ is significant and $>0.05$ is not significant. The relation between sex and each of sternal measurement in the known studied persons was analyzed by simple logistic regression analysis. The significance of all sternal measurements in the known studied persons and developing a model equation were done by using multivarite logistic regression. Negelkerke R square was used to determine correct percentage of sex prediction in unknown bodies. The expontial B (Odds ratio) was used to quantify the efficiency of each sternal measurements in sex determination in Upper Egyptians (Kirkwood and Sterner, 2003).

\section{Results}

Table (1) and figure (2): Show the mean, standard deviation (SD) and percentage of sex distributions among different age groups of the studied Upper Egyptian sample used in sternal measurements. The ages range between 18-80 years. The maximum percentage of cases were between $>40-60$ years. The mean age of males is $46.21+3.4$ years and that of females is $47.1+3.3$ years.

Table (2): Shows student " $t$ ' test statistical analysis of sternal measurements of the studied Upper Egyptian sample by MSCT. The means of all sternal measurements were higher in males than females except the sterna index. There was a highly significant difference between males and females as regard the mean of manubrium length was $(53.63+5.45 \mathrm{~mm})$ in males and $(48.92+4.29 \mathrm{~mm})$ in females, sternal body length $(110.00 \pm 11.70 \mathrm{~mm})$ in males and $(85.22 \pm 8.59 \mathrm{~mm})$ in females, combined 
length of manubrium and sternal body $(159.91 \pm 14.13$ $\mathrm{mm})$ in males and $(134.25 \pm 9.16 \mathrm{~mm})$ in females, sternal index $(49.34 \pm 7.54)$ in males and $(58.02 \pm 8.01)$ in females, width of manubrium base $(63.33+6.16$ $\mathrm{mm})$ in males and $(51.78+6.28 \mathrm{~mm})$ in females, width of manubrium waist $(61.84+8.36 \mathrm{~mm})$ in males and $(52.56 \pm 8.58 \mathrm{~mm})$ in females, width of sternal body at $2^{\text {nd }}$ ribs $(32.44+3.32 \mathrm{~mm})$ in males and $(25.67 \pm 3.74 \mathrm{~mm})$ in females, width of sternal body at $4^{\text {th }}$ ribs $(38.22 \pm 6.24 \mathrm{~mm})$ in males and $(34.08 \pm 6.73$ $\mathrm{mm})$ in females, width of the body at $6^{\text {th }}$ ribs $(33.67+6.1 \mathrm{~mm})$ in males and $(27.06 \pm 5.7)$ in females, Angle 1 was $\left(170.22 \pm 2.9^{\circ}\right)$ in males and $\left(163.7 \pm 5.7^{\circ}\right)$ in females ( $\mathrm{P}$ value $\leq=0.01)$. There was a significant difference between males and females as regard the mean width of manubrium tip $(30.33 \pm 6.46 \mathrm{~mm})$ in males and $(25.22 \pm 3.75 \mathrm{~mm})$ in females, width of body at $3 \mathrm{rd}$ ribs $(32.56 \pm 4.22 \mathrm{~mm})$ in males and $(27.89 \pm 3.26 \mathrm{~mm})$ in females, width of the body at $5^{\text {th }}$ ribs $(36.92 \pm 5.64 \mathrm{~mm})$ in males and $(33.77 \pm 6.43 \mathrm{~mm})$ in females. Angle 2 was $\left(34+5.1^{\circ}\right)$ in males and $\left(28.1+6.2^{\circ}\right)$ in females $(\mathrm{P}$ value $\leq=0.05)$.

Table (3): Shows discriminant function equations and cross-validated classification accuracies for sternal measurements of the studied Upper Egyptians. The correct percentage of sex prediction by multivariate logistic regression $92.3 \%$ in males and $93.7 \%$ in females and $93.3 \%$ of overall sex percent.

Table (4): Shows the multivariate logistic regression to predict sex from all sternal measurements in studied Upper Egyptian sample. Significance was found with manubrium length, body length, combined length, width of manubrium waist, width of body at $4^{\text {th }}$ rib, width of body at $6^{\text {th }}$ rib and angle 2. The obtained model formula $\operatorname{Sex}=51.64-1.55$ length manubrium -1.48 length body +1.26 combined length -0.15 width of manubrium waist 0.113 width of sternal body at $4^{\text {th }}$ ribs -0.23 width of body at $6^{\text {th }}$ ribs -0.14 angle 2 .
Table (5): Shows the correct percentage of sex prediction from sternal measurements by multivariate logistic regression in unknown Upper Egyptians. The model equation gives over all $85.4 \%$ correct percentage in unknown bodies.

Table (6) and figure (3): Show the percentage for the significant sternal measurements in the studied Upper Egyptian sample using simple logistic regression equation. The combined manubrium and body length represented the highest significant parameter which represented $92 \%$ in males, $92.4 \%$ in females, and $92.2 \%$ of total followed by manubrium waist width which $90.7 \%$ in males, $91.6 \%$ in females, and $89.9 \%$ of total.

Table (7): Shows equation for sex determination for every significant parameter of sternal measurements in studied Upper Egyptian population. Sex can be determined by the following equations. 11.7-21x Manubrium length, 20.6-0.21x Body length, 8.4-0.34 x Combined (M+B) length, (22.1-0.18 x Width manubrium waist), (18.7-0.18 x Width of sternal body at 4th rib), (20.1-0.21 x Width of body at 6 th rib), (23.4-0.16 Second sternal angle). The most significant is combined manubrium and body length where Exp. (B) is 0.911 then Width of sternal body at level of 4 th rib where Exp. (B) is 0.857 .

Figure (4): Shows photographs of sternum belongs to Upper Egyptian males in different age groups by MSCT.

Figure (5): Shows the photograps of females sternum in different age groups by MSCT.

Model equation

Sex $=51.64-1.55 x$ manubrium length -1.48 body length $\pm 1.26 \mathrm{x}$ combined $(\mathrm{M}+\mathrm{B})$ length $-0.15 \mathrm{x}$ width of manubrium waist $-0.113 \mathrm{x}$ width of the body at $4^{\text {th }}$ ribs $-0.23 \mathrm{x}$ width of the body at $6^{\text {th }}$ ribs -0.14 $\mathrm{x}$ lower (second) sternal angle Exp. = Exponential

Table (1): Mean, standard deviation (SD) and percentage of sex distribution among different age groups of the studied Upper Egyptian sample.

\begin{tabular}{|c|c|c|c|c|c|c|}
\hline \multirow{2}{*}{$\begin{array}{c}\text { Age } \\
\text { Groups }\end{array}$} & \multicolumn{6}{|c|}{ Mex distribution } \\
\cline { 2 - 7 } & No. & $\%$ & Mean+SD & No. & $\%$ & Mean+SD \\
\hline $18-20 Y$. & 3 & 3.75 & $19.3 \pm 0.5$ & 3 & 3.75 & $19 \pm 0.8$ \\
\hline$>20-30$ Y. & 8 & 10 & $24.6 \pm 3.9$ & 7 & 8.75 & $26.8 \pm 3.3$ \\
\hline$>30-40$ Y. & 12 & 15 & $35.9 \pm 3.2$ & 12 & 15 & $36.5 \pm 3.2$ \\
\hline$>40-50$ Y. & 17 & 21.25 & $46.16 \pm 3.1$ & 18 & 22.5 & $45.8 \pm 3.4$ \\
\hline$>50-60$ Y. & 18 & 22.5 & $55.53 \pm 2.8$ & 19 & 23.75 & $56.2 \pm 3.1$ \\
\hline$>60-70$ Y. & 13 & 16.255 & $65.9 \pm 3.6$ & 15 & 18.75 & $67.1 \pm 3.6$ \\
\hline$>70-80$ Y. & 9 & 11.25 & $76.4 \pm 3.5$ & 6 & 7.5 & $77.4 \pm 3.2$ \\
\hline Total & 80 & 100.0 & $46.25 \pm 3.5$ & 80 & 100.0 & $47.1 \pm 3.3$ \\
\hline
\end{tabular}


Table (2): Student " $t$ " test statistical analysis of sternal measurements of the studied Upper Egyptian sample by MSCT.

\begin{tabular}{|c|c|c|c|c|}
\hline \multirow{2}{*}{ Sternal measurements } & Males & Females & \multirow{2}{*}{ t. value } & \multirow{2}{*}{ P. value } \\
\hline & Mean \pm SD $(\mathrm{mm})$ & Mean \pm SD $(\mathrm{mm})$ & & \\
\hline Manubrium (M) length & $53.63 \pm 5.45$ & $48.92 \pm 4.29$ & 6.76 & $<0.001 * *$ \\
\hline Sternal body (B) length & $110.00 \pm 11.70$ & $85.22+8.59$ & 15.22 & $<0.001 * *$ \\
\hline $\begin{array}{l}\text { Combined }(\mathrm{M}+\mathrm{B}) \text { length } \\
\text { (Total length) }\end{array}$ & $159.91+14.13$ & $134.25+9.16$ & 16.45 & $<0.001 * *$ \\
\hline Sternal index & $49.34 \pm 7.54$ & $58.02 \pm 8.01$ & 13.41 & $<0.001 * *$ \\
\hline Manubrium base width & $63.33 \pm 6.16$ & $51.78+6.28$ & 7.15 & $<0.001 * *$ \\
\hline Manubrium waist width & $61.84 \pm 8.36$ & $52.56+8.58$ & 6.94 & $<0.001 * *$ \\
\hline Manubrium tip width & $30.33 \pm 6.46$ & $25.25 \pm 3.75$ & 2.15 & $0.048^{*}$ \\
\hline Body width at $2^{\text {th }}$ ribs & $32.44 \pm 3.32$ & $25.67 \pm 3.74$ & 8.42 & $<0.001 * *$ \\
\hline Body width at $3^{\text {th }}$ ribs & $32.56+4.22$ & $27.89 \pm 3.26$ & 2.41 & $0.018^{*}$ \\
\hline Body width at $4^{\text {th }}$ ribs & $38.22+6.24$ & $34.08+6.73$ & 5.45 & $<0.001 * *$ \\
\hline Body width at $5^{\text {th }}$ ribs & $36.92 \pm 5.64$ & $33.77 \pm 6.43$ & 2.01 & $0.049 *$ \\
\hline Body width at $6^{\text {th }}$ ribs & $33.67 \pm 6.1$ & $27.06 \pm 5.7$ & 4.45 & $0.007 * *$ \\
\hline Upper $\left(1^{\text {st }}\right)$ sternal angle $(\mathrm{Rt}+\mathrm{Lt})$ & $170.22 \pm 2.9$ & $163.7 \pm 5.7$ & 4.22 & $0.005 * *$ \\
\hline Lower $\left(2^{\text {nd }}\right)$ sternal angle & $34+5.1$ & $28.1 \pm 6.2$ & 2.18 & $0.028 *$ \\
\hline
\end{tabular}

$P$. value $^{* *} \leq=0.01$ highly significant, $* \leq=0.05$ significant, $>0.05$ not significant $(\mathrm{Ns})$

Table (3): Discriminant function equations and cross-validated classification accuracies for sternal dimensions of the studied Upper Egyptian sample by MSCT.

\begin{tabular}{|l|l|c|c|c|}
\hline \multirow{2}{*}{ Studied populations } & \multicolumn{2}{|c|}{ Predicted Sex No. } & Percentage Correct \\
\cline { 3 - 4 } & Males & Females & \begin{tabular}{c} 
oquation \\
\hline \multirow{2}{*}{ Observed }
\end{tabular} \\
\cline { 2 - 4 } & Males $(\mathrm{n}=80)$ & 74 & 6 & $(92.3)$ \\
\hline Ovemales $(\mathrm{n}=80)$ & 5 & 75 & $(93.75)$ \\
\hline
\end{tabular}

Table (4): Multivariate logistic regression to predict sex from sternal dimensions of the studied Upper Egyptian sample by MSCT.

\begin{tabular}{|l|c|c|c|}
\hline \multicolumn{1}{|c|}{ Sternal measurements } & B & $\begin{array}{c}\text { Exp. (B) } \\
\text { (Odds ratio) }\end{array}$ & P. value \\
\hline Manubrium (M) length & -1.550 & 1.092 & $0.000^{* *}$ \\
\hline Sternal body (B) length & -1.480 & 1.279 & $0.001^{* *}$ \\
\hline $\begin{array}{l}\text { Combined (M+B) length } \\
\text { or total length }\end{array}$ & 1.256 & 3.513 & $0.000^{* *}$ \\
\hline Width of manubrium base & -0.006 & 0.694 & 0.978 \\
\hline Width of manubrium waist & -0.150 & 1.981 & $0.019^{*}$ \\
\hline Width of manubrium tip & -0.019 & 0.661 & 0.897 \\
\hline Width of body at $2^{\text {nd }}$ rib & -0.157 & 0.563 & 0.706 \\
\hline Width of body at $3^{\text {rd }}$ rib & 0.246 & 0.363 & 0.369 \\
\hline Width of body at $4^{\text {th }}$ rib & -0.113 & 0.981 & $0.042^{*}$ \\
\hline Width of body at $5^{\text {th }}$ rib & 0.179 & 0.771 & 0.101 \\
\hline Width of body at $6^{\text {th }}$ rib & -0.231 & 0.861 & $0.044^{*}$ \\
\hline Upper $\left(1^{\text {st }}\right)$ sternal angle $(\mathrm{Rt}+\mathrm{Lt})$ & -0.142 & 0.779 & 0.493 \\
\hline Lower $\left(2^{\text {nd }}\right)$ sternal angle & 0.088 & $1.092 * *$ & 0.022 \\
\hline Constant & 51.638 & & 0.001 \\
\hline
\end{tabular}

$P$. value $^{* *} \leq=0.01$ highly significant, $* \leq=0.05$ significant, $>0.05$ not significant (Ns). 
Table (5): The correct percentage of sex prediction from sternal measurements by multivariate logistic regression in unknown Upper Egyptian persons by MSCT.

\begin{tabular}{|l|c|c|}
\hline \multicolumn{3}{|c|}{ Model Summary } \\
\hline-2 Log likelihood & Cox \& Snell R Square & Nagelkerke R Square \\
\hline 67.174 & 0.598 & $0.854 \times 100$ \\
\hline
\end{tabular}

Sex prediction $=$ Nagelkerke $R$ Square $\times 100=85.4 \%$

Table (6): Simple logistic regression equation for the significant sternal measurements in the studied Upper Egyptian sample by MSCT.

\begin{tabular}{|l|l|c|c|c|}
\hline \multirow{2}{*}{ Sex Vs. } & Nagelkerke R & \multicolumn{3}{|c|}{ Predicted (Percentage Correct) } \\
\cline { 3 - 5 } & Square & Male & Female & Total (\%) \\
\hline Manubrium length & 0.768 & 88.6 & 87.6 & 88.1 \\
\hline Sternal body length & 0.779 & 89.4 & 89.2 & 89.3 \\
\hline $\begin{array}{l}\text { Combined (M+B) length } \\
\text { (total length) }\end{array}$ & 0.871 & 92 & 92.4 & 92.2 \\
\hline Manubrium waist width & 0.857 & 90.8 & 91.2 & 91 \\
\hline Sternal body width at 4 & & & \\
\hline Sternal body width at $6^{\text {th }}$ ribs & 0.847 & 90.2 & 91.4 & 90.8 \\
\hline Second sternal angle & 0.817 & 90.1 & 91.2 & 90.6 \\
\hline
\end{tabular}

Table (7): Equation for sex determination for the significant sternal measurements in studied Upper Egyptian sample by MSCT.

\begin{tabular}{|l|c|l|l|}
\hline \multicolumn{1}{|c|}{ Parameters } & Sig. & Exp. (B) & \multicolumn{1}{c|}{ Equation (sex=) } \\
\hline Manubrium length & 0.003 & 0.808 & $11.7-21$ Manubrium length \\
\hline Body length & 0.005 & 0.815 & $20.6-0.21$ Body length \\
\hline Combined (M+B) length or total length & 0.001 & 0.911 & $8.4-0.34$ Combined (M+B) length \\
\hline Manubrium waist width & 0.031 & 0.764 & $22.1-0.18$ Width manubrium waist \\
\hline Body width at $4^{\text {th }}$ rib & 0.019 & 0.857 & $18.7-0.18$ Width of body at $4^{\text {th }}$ rib \\
\hline Body width at $6^{\text {th }}$ rib & 0.041 & 0.521 & $20.1-0.21$ Width of body at $6^{\text {th }}$ rib \\
\hline Second sternal angle & 0.022 & 0.761 & $23.4-0.16$ Second sternal angle \\
\hline
\end{tabular}

$P$. value $* * \leq=0.01$ highly significant, $* \leq=0.05$ significant, $>0.05$ not significant $(N s)$.

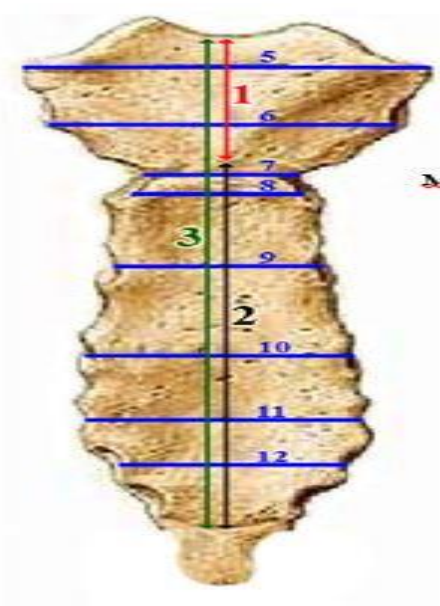

Figure 1(A)

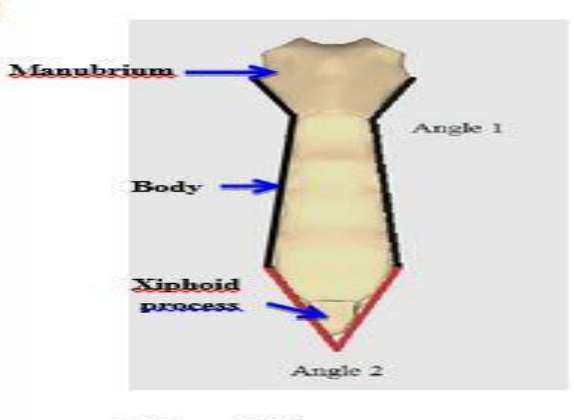

Figure 1(B)

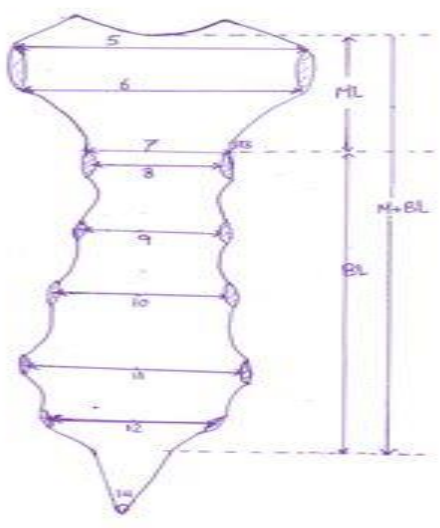

Figure 1(C)

Figure 1 (a-b-c): Schematic diagrams of all sternal measurements(1) manibrium length (ML), (2) body length (BL), (3) combined manubrium and body length $(M+B ~ L)$, (4) sternal index [(M/B) $x$ 100], (5) width of manubrium base, (6) width of manubrium waist, (7) width at tip of manubrium (8) width body at articulation of $2^{\text {nd }}$ rib, (9) width body at articulation of $3^{\text {rd }}$ rib, (10) width body at articulation of $4^{\text {th }}$ rib, (11) width of body at articulation of $5^{\text {th }}$ rib, (12) width body at articulation of $6^{\text {th }}$ rib.(13) first or upper sternal angle (14) second or lower sternal angle. 


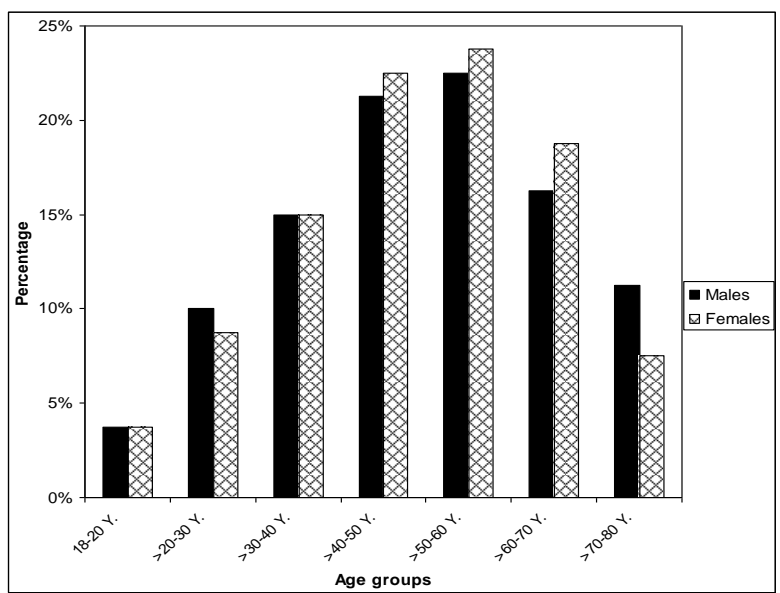

Figure (2): Shows the percentage of sex distribution among different age groups of the studied Upper Egyptian sample.

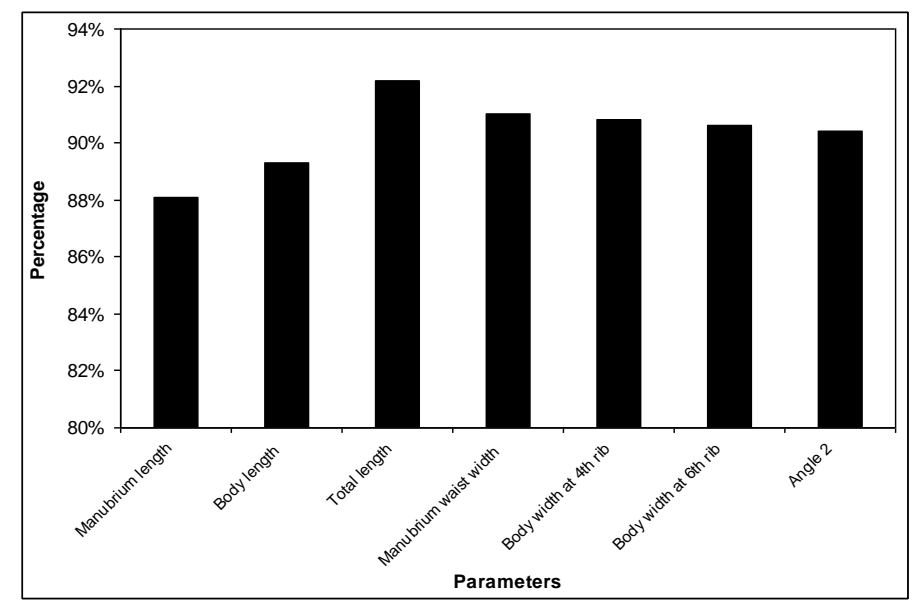

Figure (3): The percentage of the significant sternal measurements in studied Upper Egyptian sample by MSCT.

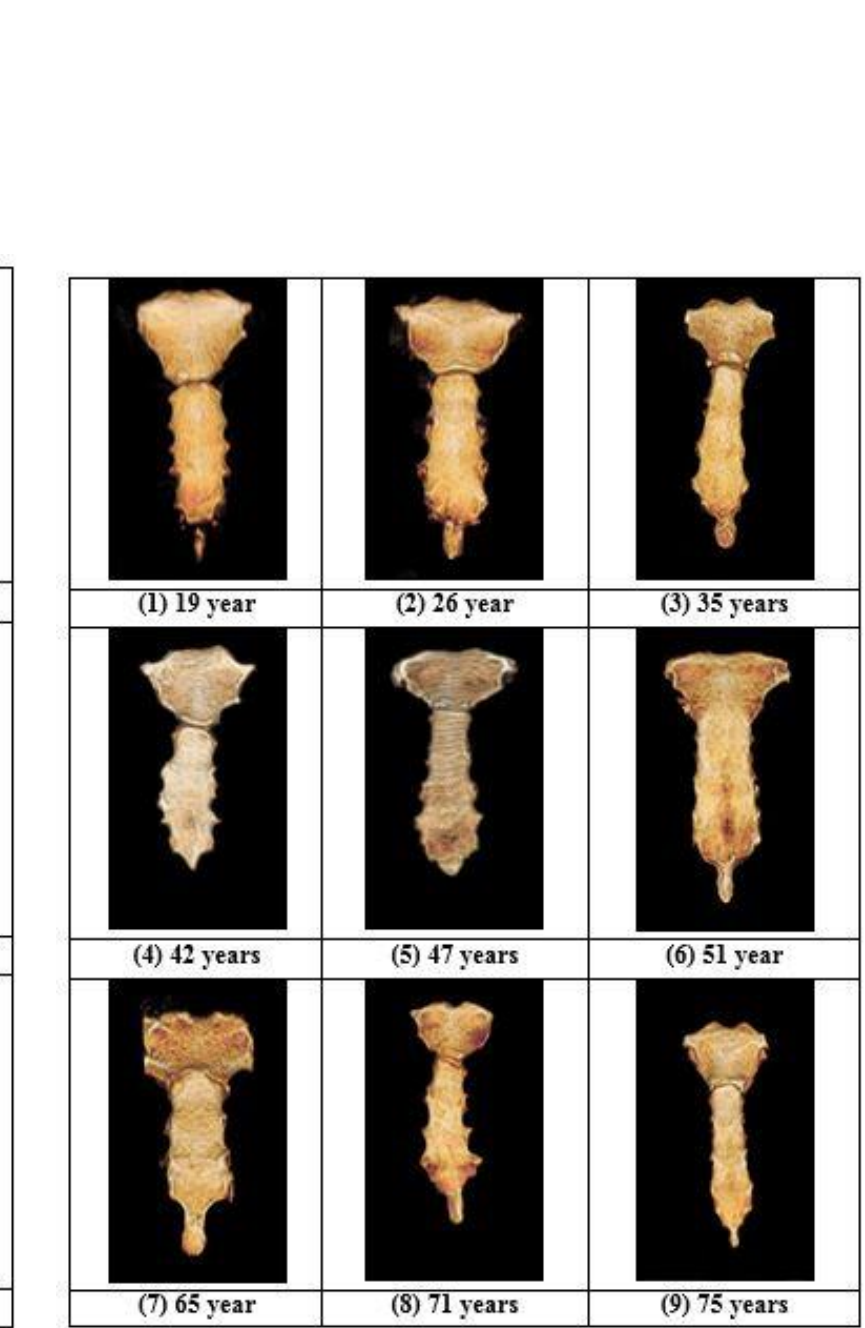

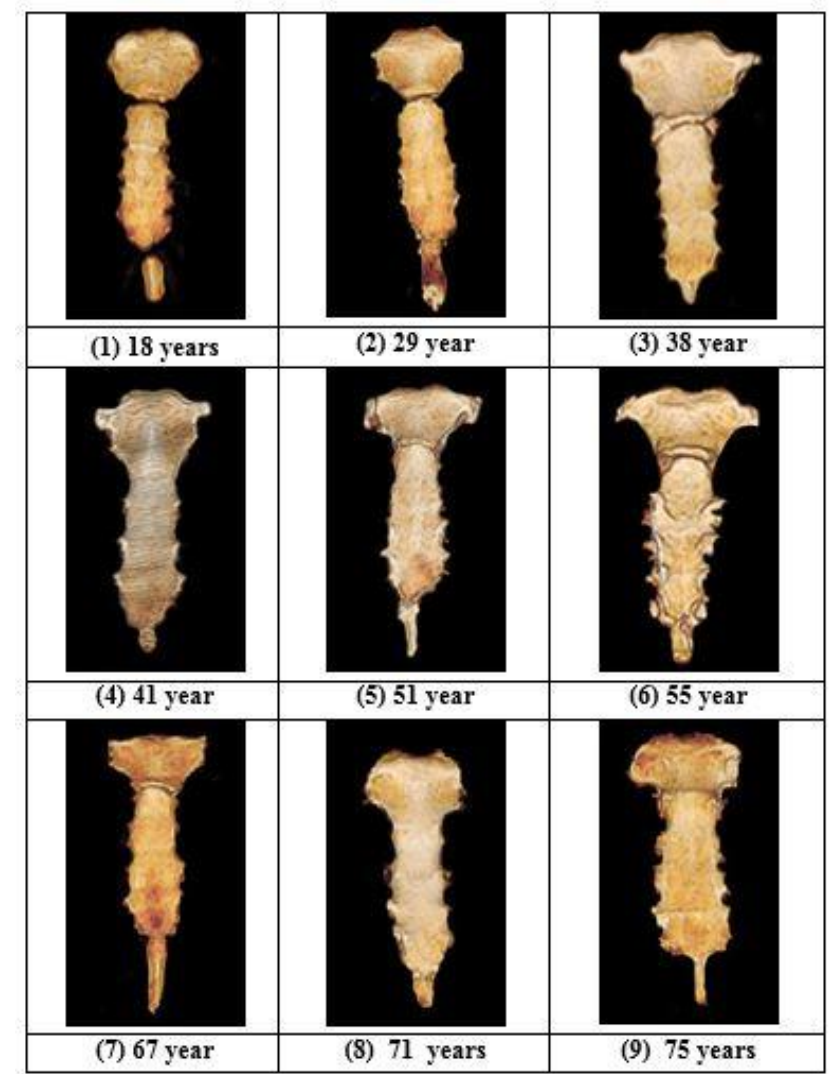

Figure (4): Photographs of sternum belongs to Upper Egyptian males of different ages by MSCT
Figure (5): Photographs of sternum belongs to Upper

Egyptian females of different ages by MSCT 


\section{Discussion}

Proper personal identification of living or deceased persons is important in civil and criminal proceedings. The techniques of identifying an individual are varied and depend upon the circumstances of each particular case and whether a complete or dismembered body parts or only bones are available (Singh et al., 2012). Sex determination is an important process in establishing the identity of an individual. This can be helped by use of MSCT (Uthman et al., 2011).

The multidetector computed tomography can give rapid and accurate results in identification of victims in mass disasters and juridical reasons. It can be used effectively for analysis skeletal structures, provides clear unambiguous images in different areas without distortion or overlapping of other anatomical structures, capable of distinguishing finer details than conventional radiography and able to provide slice thickness down to $1 \mathrm{~mm}$ or less (Sidler et al., 2007).

Discriminant function analysis of bone measurements has become important step in forensic anthropology. It is always used for sex determination from different bone measurements (Kranioti et al., 2009). Studies conducted so far have demonstrated that populations differ from one another in size and proportion. Therefore, the discriminant formulae developed for determining sex for one population group cannot be applied on another (Bongiovanni and Spradley 2012).

The present work investigated the possibility of determination of sex from various sternal measurements in known Upper Egypt sample population by MSCT. Then to develop equations for sex determination for unknown Upper Egyptians.

The results of the present work demonstrated that the manubrium length, sternal body length, manubrium width and combined length of manubrium and sternum were found to be larger in male than females. The sternal index is found to be significantly higher in females than males.

In harmony with results of the present work was study of Changani et al. (2014) for determination of sex from sternal measurements by $\mathrm{CT}$ in Indian population found that the manubrium length, sternal body length, manubrium width and combined length of manubrium and sternal body were found to be larger in male than females and the difference was statistically significant.

Also in agreement the results obtained by Osunwoke et al. (2010) who studied sexual dimorphism from sternum in Nigerian population. Similar results obtained by study of Ankit et al. (2013) in population of Saurashtra region in Indian.

The sternal index is derived by dividing the length of manubrium by the length of mesosternum and multiplying it by 100 . In agreement with results of present work, the sternal index was found to be significantly higher in females (Hunnargi et al., 2009).

In the present study the combined length of manubrium and sternum was found to be the most accurate for determination of sex among all studied parameters which gives $92.2 \%$ by simple logistic regression equation.

Sex determination from sternal measurements in a Maharashtrian population of India demonstrated that the manubrium confirmed sex in $77.3 \%$ male and $77.5 \%$ female bones, the mesosternum confirmed sex in $73.3 \%$ male and $75 \%$ female bones accurately. The combined length of manubrium and mesosternum confirmed sex in $85.3 \%$ male and $77.5 \%$ female sternums correctly (Hunnargi et al., 2008).

In the present study the discriminant function equation and cross validated classification accuracies can predict sex in the studied Upper Egyptian population by $(92.3 \%)$ in males and $(93.75 \%)$ in females with average $(93 \%)$.

In the present work the multivariate logistic regression equation to predict sex was 85.4\% in unknown Upper Egyptian population.

The following multivariate logistic regression equation for sex prediction in unknown Upper Egyptian population.

Sex $=51.64-1.55$ Length manubrium -1.48 length body +1.26 total length -0.15 width manubrium waist- 0.113 width body at 4 th rib 0.23 width body at 6 th rib -0.14 angle 1 .

Significant differences were noticed between the mean of sternal measurements measured directly on bone specimens in present study and those measured by CT scan images. Comparative analysis of sternal measurements showed higher sex accuracy in Indian population. The calculated multivariate DFA equation $(y=-$ 14.222+0.076MBL+0.137WS_1) and regression equation $\quad\left(y=36.675-0.198 \mathrm{MBL}-0.405 \mathrm{WS} \_1\right)$ correctly estimated sex of $84.8 \%$ (males) and $89.8 \%$ (females sternums, respectively.

Multivariate analyses gave more striking results than the univariate ones. Although logistic regression analysis gave higher accuracy rates but discriminant function analysis was found to be a more reliable statistical tool for sex determination because of low sex biases (Singh and Pathak, 2013).

A study of sterna measurements in American (Black and American). The discriminate function analysis produced an overall crossvalidation classification rate of $84.12 \%$ for sex estimation. The cross-validation classification rate for males and females was $80 \%$ and $88.24 \%$, respectively (Bongiovanni and Spradley 2012). 
In South Africa a stepwise discriminant function procedure, which selected corpus sterni length and manubrium width, correctly identified sex by $86.4 \%$ of the individuals in the study sample. Additional multivariate discriminant equations incorporating dimensions for either the manubrium or corpus sterni yielded sex prediction rates of $80.6 \%$ and $84.5 \%$, respectively. Sternal area, when used in isolation, produced the highest sex classification accuracy with $86.9 \%$ of specimens correctly. The remaining single variable functions, which can be applied when wellpreserved or complete sternum are not available for analysis, provided classification accuracies ranging from $68.4 \%$ to $83.5 \%$ (Macaluso, 2010).

A study of sexual dimorphism n Spanish population in which the sternal measurements were recorded from posteroanterior digital radiographs of the chest plate of living Spanish individuals. Results demonstrated that all linear dimensions of the manubrium and mesosternum, combined length, and sternal index were significantly sexually dimorphic in this population group. Discriminant function analyses incorporating several of these variables, individually or in combination, provided sex classification accuracy rates greater than $80.0 \%$, with associated sex biases below 5.0\%. A stepwise procedure, which can be used when a complete sternum is present, yielded the highest correct sex classification rate at $89.7 \%$ (Macaluso and Lucena, 2014).

Logistic regression analysis of measurements of the sternum and 4th rib width through thoracic radiograhs was undertaken to determine sex. Showed that sex was predicted at an accuracy of $95.8 \%$ for males and $90.3 \%$ for females (Torwalt and Hoppa, 2005)

In Australia, multislice spiral computed tomography) descriptive statistics and discriminant function analyses. The combined length of the manubrium and body, sternal body length, manubrium width, and corpus sterni width at first sternebra contribute significantly to sex discrimination and yield the smallest sex-biases. Cross-validated classification accuracies, i.e., univariate, stepwise and direct function, are 72.2$84.5 \%$ (Franklin et al., 2012).

In this study the multivariant logistic regression females showed a slightly greater tendency of being correctly classified. This was in agreement with the study of Singh et al. (2012) who reported that the females showed a slightly greater tendency of being correctly classified. DFA correctly classified bout $84 \%$ sternums (males $=82.1 \%$, females $=89.0 \%$ ) and on cross-validation, about $82.8 \%$ cases were correctly assigned to their correct sex. So, we can say that if an unknown sternum is encountered in any forensic situation, then its sex can be estimated with about $84 \%$ accuracy by placing the values of its measurements.

In the present work. The simple logistic regression equation for every significant parameter of sternal measurements in studied Upper Egyptian populations was done. The results revealed possibility of sex prediction from manubrium or body when they present separate. The manubrium length $(88.1 \%)$, manubrium waist width $(91 \%)$, sternal body measurements (body length (89.3\%), total body and manubrium $(92.2 \%)$, body width at $4^{\text {th }}$ rib $(90.8 \%)$, body width at $6^{\text {th }}$ rib $(90.6 \%)$, sternal angle $2(90.4 \%)$.

The importance of the present study lies in the fact that this is the first study to report the use of sternal dimensions in sex determination in Upper Egyptian populations, by use of multislice computed tomography and to develop a model equation for sex prediction. Also the first study use the measured virtual sternal angles by MSCT. The use of sternum may be of value in cases of difficult identification as dismembered human remains which may be found in mass disasters and criminal mutilation is a difficult task for the medicolegal experts (Kanchan and Krishan, 2011).

\section{Conclusions and recommendations}

The different sternal measurements are reliable predictors for sexual dimorphism. The virtual sternal angles used in the study are of value in sex prediction. Although there is possibility of sex prediction if the manubrium or the body alone was available but the high percentage was obtained when the measurements were taken from the whole sternum. The model equation for sex estimation in Upper Egyptian population sample from sternal dimensions can be used by medicolegal physicians in living and dead, whether complete skeleton or dismembered remains related to chest regions are brought for forensic examination and can be accepted by law agencies. These equations should be applied only to Upper Egyptian population. The MSCT scanning is a very helpful tool for imaging the sternum and effective in sex identification. 


\section{References}

Abd-elhakim S, El-sherbeney A, Ahmed A, et al. (2012): Estimation of sex of Egyptian population by $3 \mathrm{D}$ computerized tomography of the pars petrosa ossis temporalis". Egypt J. Forensic Sci.; 2(1): 29-32.

Amin MF and Hassan EI (2012): Sex identification in Egyptian population using multidetector computed tomography of the maxillary sinus. J. Forensic Leg. Med. Feb;19(2):65-9.

Ankit VA, Monika AA, Suresh PR, et al. (2013): A Study of sexual dimorphism in human sterna. Int J Med Res Health Sci. 2013;2(3): 577-81.

Benazzi S, Bertelli P, Lippi B, et al. (2010): Virtual anthropology and arts: the facial reconstruction of Ferrante Gonzaga. J. Archaeol. Sci., 37 : 1572-157.

Bongiovanni R and Spradley MK (2012): Estimating sex of the human skeleton based on metrics of the sternum. Forensic Sci. Int. Jun10;219(1-3):290.e1-7. Changani MV, Javia MD, Kulin A, et al (2014): Determination of sex from various measurements of human sternum and manubrium in Gujarat population. J. Res. Med. Den. Sci.; 2(1):59-65.

Decker SJ, Davy-Jow SL, Ford JM et al. (2011): Virtual determination of sex: metric and nonmetric traits of the adult pelvis from 3D computed tomography models. J Forensic Sci. Sep; 56(5):1107-14.

Dirnhofer R, Jackowski C and Vock P (2006): Virotopsy: minimally invasive, imagingguided virtual autopsy. Radio -graphics, 26:1305-1333.

Eshak GA, Ahmed HM and Abdel Gawad EAM (2011): Gender determination from hand bones length and volume using

Kimmerle EH, Prince DA and Berg GE (2008): Inter-observer variation in methodologies multidetector computed tomography: A

study in Egyptian people. J.

Forensic Legal Medicine; August 18 (6):

246-252.

Franklin D, Flavel A, Kuliukas A, et al. (2012): Estimationof sex from sternal measurements in a Western Australian population.Forensic Sci Int. Apr 10;217(1-3):230.e1-5

Hunnargi SA, Menezes RG Kanchan T, et al. (2008): Sexual dimorphism of the human sternum in a Maharashtrian population of India: a morphometric analysis. Leg Med (Tokyo). Jan;10(1):6-10.

HunnargiSA, Menezes RG, Kanchan T, et al. (2009): Sternal index: Is it a reliable indicator of sex in the Maharashtrian population of India?. J Forensic Leg Med. Feb;16(2):56-8.

Iscan MY (1985): Osteometric analysis of sexual dimorphism in the sternal end of the rib, $\mathrm{J}$. Forensic Sci. 30 : 1090-99.

Kanchan T and Krishan K (2011): Anthropometry of hand in sex determination of dismembered remains - A review of literature. J. Forensic Leg. Med; Jan;18(1):14-7.

Kellinghaus M, Schulz R, Vieth V et al. (2010): Forensic age estimation in living subjects based on the ossification status of the medial clavicular epiphysis as revealed by thin-slice multidetector computed tomography. Int J Legal Med. Mar;124(2):149-54.

Kharoshah MA, Almadani O, Ghaleb SS, et al. (2010): Sexual dimorphism of the mandible in a modern Egyptian population. J. Forensic Leg Med. May; 17 (4):213-5 
involving the pubic

symphysis, sternal ribs, and teeth. J

Forensic Sci. May; 53(3):594-600.

Leth PM (2009): Computerized tomography used as a routine procedure at postmortem investigations. Am. J. Forensic Med. Pathol. Sep;30(3):219-22.

López-AlcarazM, GaramendiGonzález PM, Alemán Aguilera I, et al. (2013): Image analysis of pubic bone for sex determination in a computed tomography sample.Nov;127(6):1145-55.

Macaluso PJ (2010): The efficacy of sternal measurements for sex for sex estimation in South African blacks. Forensic Sci. Int. Oct.10; 202(1-3):111.e1-7.

Macaluso PJ and Lucena J (2014): Estimation of sex from sternal dimensions derived from chest plate radiographs in contemporary Spaniards. Int. J. Legal Med. Mar;128(2):389-95.

Mostafa EM, El-Elemi AH, El-Beblawy MA, et al. (2012): Adult sex identification using digital radio-graphs of the proximal epiphysis of the femur at Suez Canal University Hospital in Ismailia, Egypt. Egy. J. Forensic Sci., Sep; 2(3): 81-88.

Osunwoke EA, Gwunireama IU, Orish CN, et al. (2010): A study of sexual dimorphism of the human sternum in the southern

Nigerian population. J. Appl. Biosci. Feb; 1636-39.

Ramadan SU, Türkmen N, Dolgun NA, et al. (2010): Sex determination from measurements of the sternum and fourth rib using multislice computed tomography of the chest. Forensic Sci. Int. Apr; 197(13):120.e1-5.

Saladin K.S. (2010). Anatomy and Physiology: The Unity of Form and Function, $5^{\text {th }}$ Edition. New York, NY: McGraw-Hill. p. 266.

Sen J, Kanchan T and Ghosh S (2011): Sex estimation from foot dimensions in an indigenous Indian population. J Forensic Sci. Jan;56 Suppl 1:S148-53.

Sidler M, Jackowski C, Dirnhofer R, et al. (2007): Use of multislice computed tomography in disaster victim identification: advantages and limitations. Forensic Sci. Int. Jul 4; 169(2-3):118-28

Kranioti E, Vorniotakis N, Galiatsou C, et al. (2009): Sex identification and software development using digital femoral head radiographs. Forensic Sci Int ;189(1):113.e1-7
Kirkwood BR and Sterner JA (2003): Essential Medical Statistics, 2nd edition, Blackwell Science Inclusion, USA.

Singh J and Pathak RK (2013): Morphometric sexual dimorphism of human sternum in a north Indian autopsy sample: sexing efficacy of different statistical techniques and a comparison with other sexing methods. Forensic Sci Int. May; 228(1-3): 174.e1-10.

Singh J and Pathak RK and Singh D (2012): Morphometric sex determination from various sterna widths of Northwest Indian sternums collected from autopsy cadavers: A comparison of sexing methods. Egy. J. Forensic Sciences, 2:18-28.

Spradley MK and Jantz RL (2003): Skull versus postcranial elements in sex determination, in: $55^{\text {th }}$ Annual Meeting of the American Sciences Academy of Forensic, Chicago, Illinois.

Standring S (2008): Gray's anatomy the anatomical basis of clinical practice, 40th edition, Churchill Livingston-Elsevier, Edinburgh, London: p.917.

Torwalt CR and Hoppa RD (2005): A test of sex determination from measurements of chest radiographs. J Forensic Sci. Jul; 50(4):785-90.

Walker PL (2005): Greater sciatic notch morphology: sex, age and population differences. Am. J. Phys. Anthropol. Aug; 127(4):385-91.

Weber GW (2001): Virtual anthropology (VA): a call for glasnost in paleoanthropology. Anat. Rec., 265 (4) : 193-201.

Verna E, Piercecchi-Marti MD, Chaumoitre K, et al. (2013): Discrete traits of the sternum and ribs: a useful contribution to identification in forensic anthropology and medicine. J Forensic Sci. May; 58(3):571-7.

Zaher JF, El-Ameen FM and Seedhom, AE (2011): Stature estimation using anthropometric measurements from computed tomography of metacarpal bones among Egyptian population. Egy. J. Forensic Sciences; June, 1(2):103-108.

Zheng WX, Cheng FB, Cheng KL, et al (2012): Sex assessment using measurements of the first lumbar vertebra. Forensic Sci Int.Jun;219 (1-3): 285.e1-5.

Uthman AT, Al-Rawi NH, Al-Naaimi AS, et al. (2011): Evaluation of maxillary sinus dimensions in gender determination using helical CT scanning. J. Forensic Sci. Mar;56(2):403-8. 


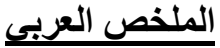

\section{تحديد الجنس من قياسات عظمة القص لأهالى صعيد مصر باستخدام الأشعة المقطعية متعددة المقاطع \\ خالا محمد عبد العال' وحازم أبوزيد يوسف}

تحديد الجنس يعتبر خطوة هامة في الإستعراف على الأشخاص و يمكن أن يتم ذلك من خحلال فحص العظام امـا بقياسها متريا مباشرا أو من خحلال صورالأشعة خاصة في حالات صعوبة الأستعراف كتقطيع الجثة والتشوهات والأنفجارات. هدفت هذه الدراسة إلى إمكانية تحديد نوع الجنس من قياسات عظمة القص باستخدام الأشعة المقطعية متعددة المقاطع وإنشاء معادلات احصائية للعلاقة بين نوع الجنس والقياسات المختلفة لعظمة القص لأهـالى صعيد مصر . أجريت الدراسة على مائة

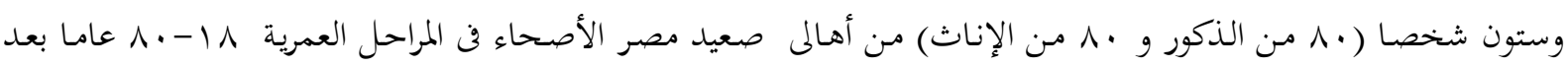
أخذذ موافقتهم الواعية أثناء فحص منطقة الصدر لهم بالأشعة المقطعية متعددة المقاطع فى قسم الأشعة التشخيصية بمستشفى أسيوط الجامعى. استخدم أربعة عشرة قياسا لعظمة القص هى أطوال رأس عظمة القص وجسمى عظمة القص ، وبحموع طول رأس وجسم عظمة القص ، ومعامل عظمة القص (حاصل قسمة طول الرأس على جسم عظمة القص X X . 1 ) ، وعرض رأس عظمة القص عند القمـة والقاعدة وعرض جسـم عظمة القص عند مستوى الضلوع الثانى، الثالث،الرابع، الخامس،السـادس والزاويتن الأفتراضيتين لعظمة القص. الزاوية الأولى عند إلتقاء الخطين الافتراضيين المتقاطعين المارين بالجانب الوحشي للجزء العلوي من جسم عظمة القص والجانب الوحشي لرأس عظم القص. والزاوية الثانية عند إلتقاء الخطين الأفتراضين المارين بالجانبين الوحشين للجزء السفلي لجسم عظم القص والنتوء الغضروفى الخنجرى). و بتحليل البيانات احصائيا وجدد أن القياسات أكبر و ذات دلالة احصائية في الذكور عن الأناث ماعدا معامل عظمة القص. تم استخدام معادلات الانحدار المتعددة والبسيطة لمعرفة نسبة صحة ومعامل تأثير كل القياسات بحتمعة أو منفردة في تحديد الجنس أن بحموع طول رأس وجسم عظمة القص مثل أعلى معامل تأثير وأعلى نسبة بين القياسات المختلفة لتتحديد المنس. أظهرت معادلة الانحدار المتعددة أن التنبؤ بنوع الجنس مـن

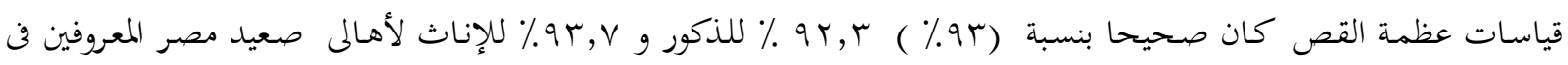
الدراسة . أثبتت المعادلة اللوجستية متعددة التغيرات أنه يمكن تحديد الجنس من قياسات عظمة القص بشكل صحيح فن لأهالى صعيد مصر بحهولى الهوية بنسبة ع, ^^٪ من قياسات عظمة القص ـ وخلصت هذه الدراسة إلى أنه يمكن إستخدام قياسات عظمة القص شاملة الزاويتن الأفتراضيتين لعظمة القص في تحديد الجنس وأن أخذا القياسات بالأشعة المقطعية متعددة المقاطع هى طريقة موثوق بها ويمكن الأعتماد عليها تحديد الجنس من العظام فن الفحص الطبي الشرعي وتكون النسبة أفضل فى حالة توافر القياسات بحتمة لكل أجزاء عظمة القص عن وجود جزء بمفرده.

$$
\text { r قسم الطب الثرعي والسموم الإكلينيكي' - كلية الطب - جامعة أسيوط }
$$

